\title{
Antecedents of Use of e-SPT and Their Impact on Taxpayer Compliance (Case Study: Special Region of Yogyakarta)
}

\author{
Juwita Andriani 1 \\ 1Sekolah Tinggi Ilmu Ekonomi YKPN Yogyakarta \\ Email: juwitaandriani057@gmail.com
}

\begin{abstract}
The development of information technology today is very helpful for all human activities such as ordering goods, buying and selling, applying for jobs, and so forth. Modernization of tax administration is carried out by the DJP as a form of improving the quality of taxation services to taxpayers, one of which is the development of debt tax reporting using electronic SPT (e-SPT) or by using computers. The population in this study is taxpayers who live in the Special Region of Yogyakarta. The sample in this study is individual taxpayers who live in the Special Region of Yogyakarta. This study uses a purposive sampling technique with criteria for taxpayers who have NPWP and taxpayers who use eSPT. The type of data used in this study is primary data obtained by researchers directly or sent via Google form. The results of this study prove that the perceived usefullnes does not affect the use of e-SPT. Perceived easy of use has a positive effect on the use of e-SPT. Security and privacy have a positive effect on the use of e-SPT. The use of e-SPT has a positive effect on tax compliance. Test equipment used in this study was SEM-PLS with 158 respondents.
\end{abstract}

Keywords: convenience, e-SPT, perceived usefulness, security and privacy, taxpayer compliance 


\section{INTRODUCTION}

Along with the times, technology has developed very rapidly. The development of information technology is currently very helpful for all human activities such as ordering goods, buying and selling, applying for jobs, and so on (Novindra and Rasmini, 2017). Sources of state revenues come from many sectors, both from the internal and external sectors. The source of income from the internal sector is the receipt of income from tax payments. Tax collection reduces individual income or wealth, but on the contrary it is community income which is then returned to the community through routine expenditures and state development expenditures that are beneficial to the people (Alim, 2013).

The modernization of tax administration carried out by the Directorate General of Taxation is a form of improving the quality of tax services for taxpayers, one of which is the development of tax payable reporting using electronic SPT (e-SPT) or by using a computer. The applicable provisions regarding the use of the e-SPT application in tax reporting have begun along with the formation of modern tax offices (Alim, 2013).

Research that can support taxpayers to use e-SPT with perceived usefulness factor. Research that supports these variables are Herawan and Waluyo (2014), Sari, Kertahadi, and NP (2014), Amin (2017), Lie and Sadjiarto (2013), Novindra and Rasmini (2017), Sari et al (2014) which is the degree to which a person believes that using a system will improve his or her performance. And also the perceived ease of use factor. Research that supports these variables are Herawan and Waluyo (2014), Sari et al (2014), Amin (2017), Lie and Sadjiarto (2013), Novindra and Rasmini (2017), which is a level where someone believes that technology can easily understood. Next is the factor of confidentiality and security (security and privacy). Research that supports these variables is Herawan and Waluyo (2014) where the use of an information system can be said to be safe if the risk of data loss is very small, and this confidentiality related to user information is only known by the owner or user so that confidentiality is guaranteed.

Research that can not support taxpayers on the use of e-SPT with factors of confidentiality and security (security and privacy). Research that supports this variable is Pricilia (2016) where there is no significant effect between security and confidentiality on the interest of individual taxpayers to use e-filling in their tax reporting. The difference between my research and previous research is that previous research used e-filing and my research used e-SPT, and my research variable added the use of e-SPT on taxpayer compliance, and the next difference is that previous research was conducted in kosambi while my research was conducted in the regions. Yogyakarta Special. So the purpose of this research is to analyze the antecedents of the use of e-SPT and its impact on taxpayer compliance. Therefore, this research is entitled "Antecedents of the Use of e-SPT and Its Impact on Taxpayer Compliance (Case study: Special Region of Yogyakarta)".

Based on the above background, the problems in this study can be formulated: First; Does the perception of usefulness have a positive effect on the use of e-SPT?. Second; Does the perception of convenience have a positive effect on the use of e-SPT?. Third; Do security and confidentiality have a positive effect on the use of e-SPT?. Fourth; Does the use of e-SPT have a positive effect on taxpayer compliance? 
The existence of a goal in this research is very important because with the right goal it is a benchmark for success in research. The research objectives to be achieved are first; to determine whether there is a positive effect of perceived usefulness on the use of e-SPT. Second; To determine whether there is a positive effect of perceived ease of use on e-SPT. Third; To find out whether there is a positive effect of security and confidentiality on the use of e-SPT. Fourth; To determine whether there is a positive effect of using e-SPT on taxpayer compliance.

Based on the formulation of the problem, the hypotheses in this study are as follows, First; Perceived usefulness has a positive effect on the use of e-SPT. Second: Perceived easy of use has a positive effect on the use of e-SPT. Third; Security and Confidentiality (Security and Privacy) has a positive effect on the use of e-SPT. Fourth: The use of e-SPT has a positive effect on taxpayer compliance.

\section{RESEARCH METHOD}

The population in this study are taxpayers who are domiciled in the Special Region of Yogyakarta. The sample in this study is an individual taxpayer domiciled in the Special Region of Yogyakarta. This study uses a purposive sampling technique with the criteria of taxpayers who have a TIN and taxpayers who use e-SPT. The type of data used in this study, namely primary data obtained by researchers directly or sent via google form. This research uses Partial Least Square (warpPLS). The evaluation of the PLS model consists of a measurement model (outer model) and a structural model (inner model) (Abdillah and Hartono, 2015). The samples taken were 180 respondents and 22 respondents did not meet the criteria. So as many as 158 respondents who can be processed further.

\section{RESEARCH RESULTS AND DISCUSSION}

\section{The effect of perceived usefulness on the use of e-SPT}

The results obtained from the perceived usefulness of the use of e-SPT indicate that $\mathrm{H} 1$ is not supported. The results of this analysis can be seen at the significance value of $p=0.48$ and the coefficient value $(\beta)=(0.01)$, meaning that the perceived usefulness variable has no effect on the use of e-SPT.

These results support previous research, namely according to Agustina's research (2018) that perceived usefulness has no effect on the use of e-filling. This is based on interviews conducted with lecturers in March 2018. Facilitating conditions such as difficulties in using electronics, lack of socialization, manual use is simpler, just a signature, while using electronics you have to fill in the data yourself, the length of time to log in to the web for information. data entry.

According to research by Okumus, Ali, Bilgihan and Ozturk (2018), it is stated that facilitation conditions affect users. This means that when facilitating conditions (eg internet) are provided or support E-SPT reporting activities, the taxpayer will use the E-SPT. The 
unsupported first hypothesis $(\mathrm{H} 1)$ may be because respondents in the study found it difficult to use the E-SPT due to the inadequate internet network.

\section{The effect of perceived ease of use on e-SPT}

The results obtained from the perception of ease of use of e-SPT indicate that $\mathrm{H} 2$ is supported. The results of this analysis can be seen in the significance value of $p<.01$ and the coefficient value $(\beta)=(0.47)$ meaning that the perceived convenience variable has a positive effect on the use of e-SPT.

These results support previous research, namely according to research by Novindra and Rasmini (2017) the effect of ease of use of e-SPT on interest in using e-SPT and the results of the convenience variable indicate that ease of use has a positive effect on interest in using e-SPT. This means that the easier it is to use e-SPT for taxpayers, the interest in using e-SPT will increase.

\section{Effect of security and confidentiality on the use of e-SPT}

The results obtained from the security and confidentiality of the use of e-SPT indicate that $\mathrm{H} 3$ is supported. The results of this analysis can be seen at the significance value of $p=$ 0.02 and the coefficient value $(\beta)=(0.21)$ meaning that the security and confidentiality variables have a positive effect on the use of e-SPT.

These results support previous research, namely according to research by Herawan and Waluyo (2014) who found that security and confidentiality had a positive effect on the interest of e-filling users. If the Taxpayer feels safe in the customer's e-Filling system and all information or data about him/herself is guaranteed to be confidential, then they will use e-filling in reporting the SPT.

\section{The effect of using e-SPT on taxpayer compliance}

The results obtained from the use of e-SPT on taxpayer compliance indicate that $\mathrm{H} 4$ is supported. The results of this analysis can be seen in the significance value of $p=0.01$ and the coefficient value $(\beta)=(0.56)$, meaning that the variable of the use of e-SPT has a positive effect on taxpayer compliance.

These results support previous research, according to research by Sabil, Pujiwidodo, and Lestiningsih (2018) and Sari et al (2014). With the results of research showing that the application of e-SPT has an effect on the compliance of individual taxpayers and corporate taxpayers. Because with the implementation of e-SPT they no longer need to come directly to the tax office and queue. Thus, it can save taxpayers time in submitting a notification letter (SPT). So that the application of e-SPT in improving taxpayer compliance.

\section{CLOSING}

\section{Conclusion}

The conclusions that can be drawn based on the results of the data analysis that have been carried out and the discussion are as follows: First; Perception of usability has no effect on the use of e-SPT. Second; Perception of convenience has a positive effect on 
the use of e-SPT. Third: Security and confidentiality have a positive effect on the use of eSPT. Fourth: The use of e-SPT has a positive effect on taxpayer compliance.

\section{Suggestions}

Suggestions from this study are further research to add variables that affect taxpayer compliance such as facilitating conditions, e-filling, tax sanctions, e-registration, and tax knowledge.

\section{REFERENCES}

Abdillah, W., \& Jogiyanto, H. (2015). Partial least Square (PIs). Yogyakarta. Andi Offset

Agustina, mega ayu. (2018). pengaruh persepsi kegunaan, persepsi kemudahan dan kepuasan terhadap penggunaan e-filing wajib pajak (studi pada pegawai negeri sipil di lingkungan iain surakarta). https://doi.org/10.1051/matecconf/201712107005

Alim. (2013). Pengaruh Kesadaran Wajib Pajak dan Sanksi Perpajakan terhadap Kepatuhan Wajib Pajak Orang Pribadi di Yogyakarta (SKRIPSI 1-34)..

Amin, A. (2017). Faktor-faktor yang mempengaruhi intensitas perilaku wajib pajak dalam penggunaan e-filing pada kantor pelayanan pajak madya makassar. STIEM Bongaya, 211-220.

Herawan, L., \& Waluyo. (2014). analisis faktor - faktor yang mempengaruhi perilaku wajib pajak terhadap pengunaan e-filling.pdf.

Lie, I., \& Sadjiarto, A. (2013). faktor - faktor yang mempengaruhi minat perilaku wajib pajak untuk menggunakan e-filling. Tax \& Accounting, 3(2), 1-15.

Mutiara Sindi Pricilia. (2016). Analisis Faktor-Faktor Yang Mempengaruhi Persepsi Wajib Pajak Orang Pribadi Untuk Minat Menggunakan E-Filing. SKRIPSI.

Novindra, ni putu bella, \& Rasmini, ni ketut. (2017). pengaruh kemudahan penggunaan, persepsi kegunaan, dan computer self efficacypada minat penggunaan e-spt. Journal of Chemical Information and Modeling, 53(9), 1689-1699. https://doi.org/10.1017/CBO9781107415324.004

Okumus, B., Ali, F., Bilgihan, A., \& Ozturk, A. B. (2018). Psychological factors influencing customers' acceptance of smartphone diet apps when ordering food at restaurants. International Journal of Hospitality Management, 72(December 2017), 67-77. https://doi.org/10.1016/j.ijhm.2018.01.001

Sabil, Pujiwidodo, D., \& Lestiningsih, A. S. (2018). Pengaruh E-Spt Pajak Penghasilan Dan Pemahaman Pajak Terhadap Kepatuhan Wajib Pajak. Jurnal SIKAP (Sistem Informasi, Keuangan, Auditing Dan Perpajakan), 2(2), 122. https://doi.org/10.32897/sikap.v2i2.67 
Sari, novi purnama, Kertahadi, \& NP, maria goretti wi endang. (2014). Pengaruh Penerapan e-SPT Terhadap Kepatuhan Wajib Pajak Badan Dalam Melaporkan SPT (Studi Kasus Pada KPP Madya Malang). 1-10. 